\title{
Ağrı ilinde kaz yetiştiriciliğinin incelenmesi
}

\section{Investigation of goose breeding in Ağrı province}

\author{
Sezai ALKAN1' ${ }^{1}$, Erhan EREN² \\ ${ }^{1}$ Ordu Üniversitesi Ziraat Fakültesi Zootekni Bölümü, ORDU \\ ${ }^{2}$ Ağrı Tarım ve Orman İl Müdürlüğü, AĞRI \\ Sorumlu yazar (Corresponding author): S. Alkan, e-posta (e-mail): sezaialkan61@gmail.com \\ Yazar(lar) e-posta (Author e-mail): eren.erhan@tarimorman.gov.tr
}

\section{MAKALE BİLGİṠ}

Alınıș tarihi 30 Ocak 2019

Düzeltilme tarihi 13 Mart 2019

Kabul tarihi 25 Mart 2019

\section{Anahtar Kelimeler:}

Ağrı ili

Kaz yetiştiriciliği

Sosyal yap1

Sorun

\begin{abstract}
ÖZ
Bu araştırma, Ağrı ilinde kaz yetiştiriciliği yapılan işletmelerin genel yapısının belirlenmes amacıyla yürütülmüştür. Araştırmada Ağrı ilinin merkezinde ve ilçelerinde kaz yetiştiriciliğ yapan 151 aile işletmesinde uygulanan anketlerden elde edilen veriler kullanılmıştır. Araștırma sonuçlarına göre, yetiștiricilerin \%49.67'sinin 40-59 yaș arasında, \%48.34'ünün ilkokul mezunu ve \%56.29'unda ise hane genişliğinin 4-6 kişi arasında olduğu belirlenmiştir. Yetiştiricilerin \%85.43'ü kaz yetiştiriciliği dışında başka hayvancıllk faaliyetiyle uğraşmaktadır. Yetiştiricilerin \%64.9'u kaz yetiştiriciliğini tüketim alışkanlığı olduğu için yaptığını belirtmiştir. Kaz yetiştiriciliği süresinin işletmelerin \%63.58'inde 1-10 yıl arasında değiștiği belirlenmiștir. İșletmelerin \%71.52'sinde kazın dıșında tavuk yetiștirilmektedir. İşletmelerin sadece \%4.64'ünde kaz dışında başka kanatlı hayvan yetiştirilmemektedir. Yetiştiricilerin \%73.51'i kaz sayısını arttırmak istediğini belirtmiştir. İşletmelerin \% 98.68'inde kuluçka makinesi kullanılmamakta ve \%49.01'inde ise dezenfeksiyon yapılmamaktadır. Yetiştiricilerin \%62.91'I kazları 5-6 yıl süreyle damızlık olarak kullanmaktadır. Yetiștiricilerin \%90.73'ü kazları 8-12 aylık yaşta kesmektedir. Yine yetiştiricilerin \%84.77'si kaz üretimine devam etmek istediklerini ve karşılaştıkları en önemli sorunun hastalıklardan kaynaklanan kayıplar (\%19.86) olduğunu belirtmişlerdir.
\end{abstract}

\section{ARTICLE INFO}

Received 30 January 2019

Received in revised form 13 March 2019

Accepted 25 March 2019

\section{Keywords:}

Ağrı province

Goose breeding

Social status

Problem

\begin{abstract}
This research was conducted to determine the general structure of the goose breeding enterprises located in Ağrı province. In the study, data obtained from 151 family-owned goose breeding enterprises located in the center and districts of Ağrı province by interviewing were used. According to the results of the research, $49.67 \%$ of the breeders were between the ages of $40-59,48.34 \%$ were primary school graduates and $56.29 \%$ of the households were between 4-6. $85.43 \%$ of the breeders are engaged in animal husbandry activities other than goose breeding. $64.9 \%$ of breeders stated that they made goose breeding because it was a habit of consumption. It has been found that $63.58 \%$ of enterprises surveyed have been in the market for less than 10 years. $71.52 \%$ of enterprises are also grown in chickens in addition to goose. Only $4.64 \%$ of enterprises was found not to breed poultry other than goose. $73.51 \%$ of the breeders stated that they desire to increase the number of geese that they breed. $98.68 \%$ of companies do not use incubators and $49.01 \%$ of them do not use disinfection techniques. $62.91 \%$ of the breeders keep the geeses for breeding for 5-6 years. $90.73 \%$ of the breeders slaughter the geese at the age of 8-12 months. $84.77 \%$ of the breeders stated that they want to continue the production of goose and the most important problem they encountered is the animal losses caused by the diseases that was reported to be $19.86 \%$.
\end{abstract}

\section{Giriş}

Kaz yetiştiriciliği serbest sistem kanatlı yetiştiriciliğine oldukça uygundur. Aynı zamanda kazların selüloz içeriği yüksek yemlerden ve özellikle meradan faydalanma kabiliyetlerinin yüksek olması, hastalıklara ve dış etkenlere karşı diğer kanatlı türlerine göre daha dayanıklı ve barınak gereksiniminin daha az oluşu gibi nedenlerden dolayı kaz yetiştiriciliği düşük maliyetli bir üretim şeklidir. Dünyada farklı coğrafyalarda kazanç getirici bir üretim faaliyeti olarak kaz yetiştiriciliği yapılmaktadır. $\mathrm{Bu}$ yetiştiriciliğin dağılımına baktığımızda iklimi soğuk olan Doğu Güneydoğu Asya ülkeleri ile bazı Doğu Avrupa ülkelerinde yoğunlaştığı görülmektedir (Boz ve ark. 2014; Taşkın ve ark. 2017). 
Dünya toplam kaz eti üretiminin yaklaşık \%96'sını Asya kıtası ülkeleri karşılamaktadır. Asyadaki üretimin \%99'u ise Çin'e aittir. Avrupa ülkeleri ise kaz eti üretiminde dünya üretiminin yaklaşı $\% 5$ 'ine sahiptir. Türkiye'nin Avrupa kaz eti üretimi içerisindeki payı ise yaklaşık \%1'dir. Türkiye kaz eti üretimi yıllar bazında azalma eğilimi göstermektedir (Karabulut ve ark. 2017; FAO 2013).

Türkiye'de kaz yetiştiriciliği, Güney Doğu Anadolu, Batı Karadeniz, İç Ege, Doğu Anadolu Bölgesi, Orta Anadolu, Göller Bölgesi köylerinde ve özellikle Kars, Muş, Erzurum, Ağrı ve Ardahan illerinde yapılmaktadır. Küçük ölçekteki aile işletmelerinin açıkta otlatma şeklinde sürdürdüğü geleneksel üretim yapısı; toplumun belirli kesimlerince oldukça lezzetli bulunan kaz etinin sadece bölgesel ve yöresel ev yemeklerinde kullanılmasına ve ülke genelinde yeterince tanınmamasına neden olmaktadır. Bunun yanı sıra yetiştirilen kazların yumurta veriminin az olması, bazen döllü yumurta elde edilmesinde sıkıntı yaşanması, kuluçkada karşılaşılan bazı problemler de yetiştiriciliğe olan talebi azaltmaktadır (Boz ve ark. 2014).

2017 yılı TÜİK verilerine göre Türkiye'de kaz varlığının (978 384 adet) toplam kanatlı hayvan varlığı (348 143754 adet) içindeki payı \%0.28'dir. Kaz varlığı açısından 2017 yılında Kars (264 161 adet), Muş (98 699 adet), Ardahan (73 651 adet), Kütahya (44 427 adet) ve Samsun (35 652 adet) ilk beşte yer alan illerimizdir (TÜİK 2017). Türkiye'de ilk defa 2005 yılında görülen kuş gribi (Avian influenza) salgını, insan ölümleri, bunun devamında kanatlı sektöründe oluşan kriz ve kanatlı et ürünleri tüketiminin azalması sonucunda, 2006 yılı itibariyle bu türlerin üretiminde bir düşüş meydana gelmiştir. Kuş gribi saptanan bölge ve illerde yapılan imha ve itlaf çalışmaları da bu azalmada büyük ölçüde etkili olmuştur (Boz ve ark. 2014).

2017 yılı TÜİK verilerine göre Doğu Anadolu Bölgesi'nde yer alan ve Ağrı'ya komşu olan Kars (264 161 adet), Ardahan (73 651 adet) ve Muş (98 699 adet) illerinin kaz varlığı göz önüne alındığında, Ağrı'nın bölge illerinden oldukça geride olduğu görülmektedir. Ağr1, 2017 yılı TÜİK verilerine göre 14026 adet kaz mevcudu ile (Türkiye toplam kaz varlığ içindeki payı \%1.43) 15. sırada yer almaktadır. Oysa 2013 yılı TÜIKK verilerine göre toplam kaz varlığ 1 içinde ilin payı $\% 4.16$ ve kaz sayısı 31460 adet olarak verilmiştir. Bu açıdan değerlendirildiğinde kaz varlığında ciddi bir azalma olduğu görülmektedir (TÜİK 2017). Patnos 5300 adet, Tutak 2200 adet ve Doğubeyazit 2000 adet kaz mevcudu ile Ağrı'da kaz yetiştiriciliğinin en yoğun olarak yapıldığı ilçelerdir (TÜIKK 2017).

Kazların en önemli verimleri arasında et, karaciğer ve tüy gelmektedir. Bunların yanı sıra yumurta verimi ve yağı da önemlidir. Kazların yumurta verimi Ocak-Şubat ayında başlar ve Haziran-Temmuz aylarına kadar devam eder. Bu periyot ırklara göre değişmekle birlikte yaklaşık 130 gün sürer. Daha erken yumurta üretimini uyarmak için, yumurta sezonundan önce kazların barındıkları yerde her gün 14-16 saat aydınlatma yapılabilir (Çelik 2007; Boz 2015).

Irklara göre değişmekle birlikte kazlar bir sezonda 15-60 adet yumurta verebilmektedirler. Kazlarda yumurta verimi, ilk y1llarda sonraki yıllara göre daha fazla olup, 10 yaşına kadar verimli olarak kullanılabilmekte ve yumurtaların ağırlıkları 200 grama kadar çıkabilmektedir (Tilki ve İnal 2004a, b). Kaz yumurtalarının kuluçka süresi rrklara göre 28 ile 35 gün arasında değişir. Kazlarda ortalama döllülük oranı \%60-90, kuluçka randımanı \%50-90 arasında değişmektedir (Tilki ve İnal 2004b).
Kazlar kışa girene kadar merada tutulabilir ve yumurta üretim sezonu süresince uygun bir besleme programı uygulanabilir. Beslemede iyi kalitede kaba yem kombinasyonu ve ticari kaz geliştirme yemi (pelet yem) kullanılabilir. Çevre 1Sıs1 ve kaba yem kalitesine bağlı olarak günlük toplam 115-125 $\mathrm{g}$ pelet yem verilebilir. Ticari kaz yeminin bulunmaması halinde tavuk yemleri de kullanılabilir. Yaklaşık olarak yumurta üretiminden 2 ay önce, kazlara uygun bir geliştirme yemi verilmeye başlanılmalıdır. Bu yem tek başına dengeli bir pelet yem olabileceği gibi, herhangi bir katkı maddesi içermeyen dengeli bir yem ile dane yemlerin yarı yarıya karışımı şeklinde bir yem de olabilir. Fakat ne kullanılırsa kullanılsın \%15.4-18 arasında bir ham protein sağlanmalıdır. Bu iyi bir yumurta üretimi için gereklidir (Çelik 2007).

Tamamen konsantre yemle beslemeye dayalı entansif besleme yönteminde kazlar 10-12 haftada istenilen kesim ağırlığına ulaşırken, meraya dayalı beslemelerde bu süre 20-30 haftaya kadar uzamaktadır. Entansif besi yönteminde kesim süresi kısa olmasına rağmen, besi yeterince ekonomik olmamakta ve daha yağlı bir karkas elde edilmektedir. Besinin daha ekonomik olması, ekstansif beslemeye göre besi süresinin kısaltılması ve daha az yağlı karkas elde edilebilmesi için kaba ve konsantre yemin birlikte olduğu yarı entansif besleme yöntemi önemli bir alternatif olabilir (Arslan ve Tufan 2011).

$\mathrm{Bu}$ çalışmada, Ağrı ilinin mevcut kaz varlığı bakımından bölge illerinin gerisinde kalma nedenlerinin araştırılması, il genelinde kaz popülasyonu hakkında daha sağlıklı bilgi oluşturulması, kaz yetiştiriciliği yapan ailelerin sosyo-ekonomik durumları ortaya konulması, işletme yapıları, üretim sistemleri ve yetiştirilen kaz varyetelerinin verim performanslarının incelenerek gelecek çalışmalara kaynak sağlanması amaçlanmıştır.

\section{Materyal ve Yöntem}

\subsection{Materyal}

$\mathrm{Bu}$ çalışmanın materyalini Ağrı ili ve ilçelerinde kaz yetiştiriciliği yapan aile işletmeleri oluşturmuştur. Kazlar Anatidae familyasından Anser cinsinden ilk evcilleștirilen hayvanlar arasında yer almıştır. Kazların evcilleştirilmesi M.Ö. 3000 yıllarında Mısır'da gerçekleşmiştir. Evcil kazlar çeşitli renk, görünüş ve büyüklüktedir. Dünya'da genellikle evcil kazlar yabani kazlardan daha fazladır. Evcil kazların başlıca iki tipi vardır. Bunlardan ilki; Avrupa orijinli kazlardır ve yabani Greylag kazlarından (Anser anser) orijin aldığı sanılmaktadır. İkincisi ise; Asya orjinli kazlar olup yabani Swan kazlarından (Anser cygnoides) orijin aldığı kabul edilmektedir (Pingel 2011; Boz 2015). Çekoslavakya Beyazı, Embden, Landes, Pilgrim, Pomeranian, Sentetik Ukrayna, Beyaz Macar ve Beyaz İtalyan kazı Avrupa orijinli kazlara, Çin, Huoyan ve Kuban kazı Asya orijinli kazlara örnek olarak verilebilir (Boz 2015).

\subsection{Yöntem}

\subsection{1. Çalışma evreni ve örnekleme}

Çalışmanın evrenini, 2018 yılında Ağrı ilinde Kaz yetiştiriciliği yapan işletmeler oluşturmaktadır. Çalışmanın örneklemini ise, Ağrı ilinin merkezi ve 6 ilçesinden (Patnos, Doğubayazıt, Tutak, Taşlıçay, Diyadin, Hamur) basit tesadüfi örnekleme yoluyla seçilen toplam 151 işletme oluşturmuştur.

$\mathrm{Bu}$ çalışmada veri toplama yöntemi olarak yüz yüze görüşme, veri toplama aracı olarak ise araştırma değişkenlerini 
ölçmeye yönelik olarak hazırlanmış anket formları kullanılmıştır. Anketlerin uygulanacağı işletmelere 2018 yılının Ocak-Temmuz aylarında ulaşılmış ve anketin açıklaması yaptıktan sonra işletme sahiplerinin soruları sağlıklı bir şekilde cevaplamaları sağlanmıştır. Anket formları, demografik sorunun yanısıra kaz yetiştiriciliği hakkında bilgi edinmek amacıyla hazırlanmış toplam 44 adet sorudan oluşmuştur.

\subsubsection{Istatistik değerlendirme}

Anket formları bilgisayar ortamına aktarılarak elde edilen veriler istatistik analiz ile değerlendirilmiştir. Öncelikle, ankete katılanların anket formlarında yer alan tüm sorulara verdikleri cevapların frekans analizi yapılarak hem frekans değerleri (n) hem de \% frekans değerleri hesaplanmıştır. Demografik bazı özellikler ile sorulara verilen cevaplar arasındaki ilişkileri inceleyebilmek amacıyla çapraz tablolar oluşturulmuş ve kikare testi (Chi-Square test) yapılmıştır. Ki-kare testlerinde; beklenen frekanslar 5'in üzerinde ise Pearson Ki-kare değeri $\left(\chi^{2}\right)$, 5'in altında ise Likelihood Ratio ki-kare değeri (LR $\chi^{2}$ ) hesaplanmıştır. Anketlerin değerlendirilmesinde SPSS İstatistik Paket Programı kullanılmıştır (Anonim 2008).

\section{Bulgular ve Tartışma}

\subsection{Yetiştiricilerin bireysel ve hane özelliklerine ilişkin temel bulgular}

Araştırma alanı olan Ağrı ili Merkez, Patnos, Doğubayazıt, Tutak, Taşlıçay, Diyadin ve Hamur ilçelerinde yürütülen anket çalışmasında, katılımcıların bireysel özellikleri ile ailelerin sosyo-demografik ve ekonomik özelliklerinin belirlenmesi amaciyla sorulan sorulara verilen cevaplardan frekans tabloları oluşturulmuştur. Anket uygulamasına katılan yetiştiricilerin yaş, eğitim durumları ve hane halkı sayıları Çizelge 1'de verilmiştir.

Anketi cevaplandıran kat1lımciların \%49.67'sinin 40-59, \%30.46'sının 60-80 ve \%17.88'inin 20-39 yaş aralığında olduğu belirlenmiştir. Katılımcıların içinde en az "80 üzeri"' yaş aralığında (\%1.99) katılımcı olduğu görülmektedir. Kaz yetiştiriciliğinde sürdürülebilirliğin devamı açısından genç kesimin teşviki olumlu görülmektedir. Yetiştiricilerin büyük bir kısmının (\%48.34) eğitim seviyesi ilkokul düzeyindedir. Hane halkı sayısı bakımından 4-6 birey barındıran ailelerin oranı $\% 56.29$ olarak bulunmuştur.

\subsection{Kaz Yetişstiriciliğine ilişkin temel bulgular}

Katılımcıların \%98.68'i kendi arazisi üzerinde yetiştiricilik yapmaktadır. Ankete katılanların \%64.90’ı tüketim alışkanlığı olarak, \%31.13'ü hem tüketim hem de geçime katk1 amaçlı kaz yetiştiriciliği yapmaktadır. Yetiştiricilerin \%85.43'ü diğer hayvancılık faaliyetlerinin yanı sıra kaz yetiştiriciliği yapmaktadır. Bölgede kaz yetiştiriciliği büyük oranda diğer hayvancılık faaliyetlerine ek olarak yürütülmektedir. Ayrıca ailelerin \%71.52'si kaz haricinde kanatl hayvan olarak tavuk yetiştirmektedir. Yetiştiricilerin \%63.58'i $1-10$ yıldır kaz yetiştiriciliği yaptığını ifade etmiştir. Kaz yetiştiriciliği yapan ailelerin ise \%73.51'i kaz varlığını arttırmak istediğini bildirmiştir (Çizelge 2).

Boz ve ark. 2014 tarafindan Yozgat ilinde yapılan anket çalışmasında, ankete katılan ailelerin \%85.5'inin tüketim alışkanlığı ve kendi ihtiyaçlarını karşılamak amacıyla diğer hayvancılık faaliyetlerine ek olarak kaz yetiştiriciliği yaptığını bildirmişlerdir. Ayrıca çalışmada, ailelerin \%48'inin 1-10 yıldır, \%3'ünün ise 40 yıldan fazla süredir kaz yetiştiriciliği yaptıklarını bildirmişlerdir.

Anket çalışmasında, kazların bakım ve besleme gibi uğraşlarının genelde hanedeki çocuklar ve kadınlar tarafından yapıldığı gözlemlenmiştir. Demir ve ark. (2013) tarafından Ardahan ilinde yapılan anket çalışmasında, kazların bakım ve idaresinde genellikle ev hanımlarının aktif rol aldığ 1 ve ankete katılanların \%10.34'ü tarafından kazların çobanlara baktırıldığı bildirilmiştir. Boz ve ark. 2014 ise kazların bakım ve idaresinde bütün aile bireylerinin rol aldığını ancak bayanların daha aktif rol aldıklarını bildirmişlerdir. Diker ve Deniz (2017) Türk kültüründe ve mitolojisinde önemli bir yeri olan kazın, Kars ilinin kültürel ve gastronomik kimliğindeki yerinin araştırılması üzerine yapmış oldukları çalışmada, "kaz çobanlığının" genelde kadınlar arasında yapılan bir meslek olduğunu, ve bu mesleğin imece usulü gerçekleştirildiğini bildirmişlerdir. Bu araştırmada belirlenen kazların bakım ve idaresinde ağırlıklı olarak evin kadınlarının ve çocuklarının görev alması, yapılan diğer çalı̧̧malarla benzerlik göstermektedir.

Yetiştiriciler, yetiştirdikleri kaz sayısına bağlı olarak değişmekle birlikte ortalama 4-6 adet damızlık kaz elde tutmaktadırlar. Kaz yetiştiriciliği genellikle yetiştiricilerin kendi elindeki damızlık materyalden doğal kuluçka yöntemiyle elde ettiği palazlar ile yapılmaktadır. Kendi kaynakları dışında komşulardan da kaz palazı temin edilmektedir. Yörede yetiştiricilerin kaz palazı temin edebilecekleri bir pazar olmayışından dolayı, katılımcılar "hayvan pazarı" seçeneğini işaretlememişlerdir. Demir ve ark. (2013) yapmış oldukları çalışmada, ekstansif olarak yapılan kaz yetiştiriciliğinin, yerli ırklarla ve genellikle doğal kuluçka yöntemi kullanılarak sürdürüldügünü ve ortalama 5 adet kazın (4 dişi ve 1 erkek) damızlık olarak bir sonraki seneye bırakıldığını bildirmişlerdir. Boz ve ark. (2014) kaz yetiştiriciliğinin, ailelerin kendi elindeki damızlık kaz materyalinden doğal kuluçka yöntemi ile sağladığı palazlar ile sürdürüldügünü, kendi kaynakları dışında komşudan ve hayvan pazarından da kaz temin edildiğini ve damızlık olarak 1-25 adet kazın elde tutulduğunu bildirmişlerdir. Taşkın ve ark. (2017) Kırşehir ilinde yapmış oldukları çalışmalarında işletmelerin yaklaşı 5 adet dişi ve 1 adet erkek kazı damızlık olarak elde tuttuklarını bildirmişlerdir. Bu durum yapılan çalışmada elde edilen bilgilerle paralellik göstermektedir.

Çizelge 1. İşletmelerin yaş, eğitim durumu ve hane halkı sayısına göre dağılımı.

Table 1. Distribution of enterprises by age, educational status and number of households.

\begin{tabular}{crrcrrrrr}
\hline Yaş & $(\mathrm{n})$ & $(\%)$ & Eğitim Durumu & $(\mathrm{n})$ & $(\%)$ & Hane Halkı Sayıs & $(\mathrm{n})$ & $(\%)$ \\
\hline $20-39$ & 27 & 17.88 & Okur/yazar değil & 11 & 7.28 & $1-3$ & 10 & 6.62 \\
$40-59$ & 75 & 49.67 & İlkokul & 73 & 48.34 & $4-6$ & 85 & 56.29 \\
$60-80$ & 46 & 30.46 & Ortaokul & 42 & 27.81 & $\geq 7$ & 56 & 37.09 \\
$\geq 80$ & 3 & 1.99 & Lise ve Üzeri & 25 & 16.57 & - & - & - \\
Toplam & 151 & 100.00 & & 151 & 100.00 & & 151 & 100.00 \\
\hline
\end{tabular}


Çizelge 2. İşletmelerin yetiştiricilik faaliyetlerine göre dağılımı.

Table 2. Distribution of enterprises according to breeding activities.

\begin{tabular}{|c|c|c|}
\hline \multicolumn{2}{|c|}{ Başka hayvancılık faaliyeti var mı? İşletme Sayısı } & \multirow{2}{*}{$\begin{array}{c}\text { Toplam İşletme } \\
\text { İçindeki Payı (\%) } \\
85.43\end{array}$} \\
\hline Evet & 129 & \\
\hline Hayır & 22 & 14.57 \\
\hline \multicolumn{3}{|l|}{ Yetiştirme Sebebi } \\
\hline Geçime Katkı & 2 & 1.32 \\
\hline Tüketim Alışkanlığı & 98 & 64.9 \\
\hline Hobi & 1 & 0.66 \\
\hline Geçim/Tüketim & 47 & 31.13 \\
\hline Tüketim Alışkanlığg/Hobi & 2 & 1.32 \\
\hline Geçime Katk1/Hobi & 1 & 0.66 \\
\hline \multicolumn{3}{|l|}{ Yetiştiricilik Süresi } \\
\hline $1-10$ & 96 & 63.58 \\
\hline $11-20$ & 43 & 28.48 \\
\hline $21-30$ & 10 & 6.62 \\
\hline $31-40$ & 2 & 1.32 \\
\hline \multirow{2}{*}{\multicolumn{3}{|c|}{$\begin{array}{l}\text { Yetiştiriciliği Yapılan Diğer } \\
\text { Kanatlı Hayvanlar }\end{array}$}} \\
\hline & & \\
\hline Yok & 7 & 4.64 \\
\hline Ördek & 1 & 0.66 \\
\hline Hindi & 1 & 0.66 \\
\hline Tavuk & 108 & 71.52 \\
\hline Ördek/Tavuk & 1 & 0.66 \\
\hline Hindi/Tavuk & 29 & 19.21 \\
\hline Ördek/Hindi/Tavuk & 3 & 1.99 \\
\hline Cevapsiz & 1 & 0.66 \\
\hline \multicolumn{3}{|l|}{ Kaz Varlığını Artırma İsteği } \\
\hline Evet & 111 & 73.51 \\
\hline Hayır & 40 & 26.49 \\
\hline
\end{tabular}

Yetiştiricilik yapılan ailelerde tüy rengine göre ağırlıklı olarak Alaca, Beyaz ve Gri varyeteler kullanılmaktadır. Ancak Alaca varyetenin daha fazla tercih edildiği belirlenmiştir. Boz ve ark. (2014) yetiştiricilik yapılan ailelerde tüy rengine göre Alaca, Beyaz, Gri ve Siyah olarak belirlenen kaz varyetelerinin bulunduğunu, bu varyetelerin tek veya karışı varyeteler oarak yetiștirildiğini, ancak Alaca ve Beyaz varyetenin daha fazla tercih edildiğini bildirmişlerdir. $\mathrm{Bu}$ varyetelerin tercih edilme sebebi tamamen görünüş özeliklerine dayandırılmaktadır.

\subsection{Kazların barınma ve beslenme özelliklerine ilişkin temel bulgular}

Yörede kazlar kapalı alanda barındırılmakta ve kazların tamamı gündüzleri merada otlatılmaktadır. Bu otlatma kazların çobansız olarak mera, otlak, köy alanı ve su kenarlarında otlatılması şeklinde yapılmaktadır. Kaz palazları iklim şartları da göz önünde tutularak 2 veya 3 . haftadan itibaren dişarı çıkarılmaktadır ve yetiştiricilerin \%86.75'i palazlar için ayrı bir yemleme uygulamaktadır. Yörede kazların kapalı alanda barındırılması ve kaz palazlarının geç yaşta dışarı bırakılması uzun ve sert geçen kış mevsimine dayandırılmaktadır. Yetiştiricilerin tamamı kazlara mera harici ek yemleme uygulamakta ve ek yemlemede ağırlıklı olarak arpa, buğday ve fabrika yemi kullanmaktadır. Demir ve ark. (2013) yetiştiricilerin kazlarını genellikle merada beslediklerini, ek olarak evdeki ekmek ve yemek atıklarını verdiklerini, kesim öncesinde ise yetiştiricilerin \%88.8'inin kazları arpa ile yoğun besi dönemine aldıklarını bildirmişlerdir. Boz ve ark. (2014) ise ek yemlemede kullanılan yem materyallerinin tahıllar (buğday, arpa, mısır), ev atıkları ve diğer hayvanlar için kullanılan fabrika yemleri (koyun besi yemi, sığır besi yemi) olduğunu bildirmişlerdir. Kazların merada otlatılması ile mera harici ek yemleme uygulamaları yapılan anket çalışmasında üreticilerin vermiş oldukları cevaplarla benzerlik göstermektedir.

Ankete katılanların \%50.99'u barınaklarda dezenfeksiyon uygulamas1 yapıyorken, \%49.01'i herhangi bir dezenfeksiyon uygulaması yapmamaktadır (Çizelge 3 ). Bu oran kanatlı hayvan hastalıklarının bulaşması ve yayılması açısından ciddi bir sorun olarak görülmektedir. Yetiştiricilerin \%39.74'ü hastalıklar nedeniyle kayıpların yaşandığını belirtmiştir. Demir ve ark. (2013) bu oranı \%13 olarak, Demir ve Aksu Elmalı (2012) bu oran1 \%8.74 olarak ve Boz ve ark. (2014) \%1.5 olarak bildirmişlerdir. Yapılan anket çalışmasında ölüm oranının diğer çalışmalardaki değerlerin üstünde olduğu görülmektedir. Bu durum kötü barındırma şartları, işletmelere kaçak yoldan hastalıklı hayvan girişlerinin olması ve yetiştiricilik yapılan bölgenin göçmen kuşların göç yolu üzerinde yer almasına bağlı olarak yayılan kuş gribi (Avian influenza) gibi kanatlı hastalıklarına dayandırılmaktadır. Hastalıklarla mücadele ağırlıklı olarak yetiştiricilerin kendi imkanlarıyla ve serbest veteriner hekim desteğiyle yürütülmektedir. Yetiştiricilerin $\% 78.15$ 'i barınaklarda biriken gübreyi kullanmazken, $\% 21.85$ 'i gübreyi tarlada organik gübre olarak değerlendirmektedir.

Çizelge 3. İşletmelerin kuluçka makinesi kullanımı, dezenfeksiyon uygulama ve gübre kullanımına göre dağılımı.

Table 3. Distribution of enterprises according to using of incubator, disinfection application and fertilizer.

\begin{tabular}{lcc}
\hline Kuluçka Makinesi Kullanımı & İşletme Sayısı & $\begin{array}{c}\text { Toplam İşletme } \\
\text { İçindeki Payı (\%) }\end{array}$ \\
\hline Evet & 2 & 1.32 \\
$\quad$ Hayır & 149 & 98.68 \\
Dezenfeksiyon Uygulaması & & \\
$\quad$ Evet & 77 & 50.99 \\
$\quad$ Hayır & 74 & 49.01 \\
Hastalıklar nedeniyle kayıplar & & \\
oluyor mu? & & \\
$\quad$ Evet & 60 & 39.74 \\
$\quad$ Hayır & 91 & 60.26 \\
Kaz Gübresi Kullanımı & & \\
$\quad$ Evet & 33 & 21.85 \\
$\quad$ Hayır & 118 & 78.15 \\
\hline
\end{tabular}

3.4. Kaz eti, kaz yağı ve kaz tüyünün kullanımına ilişkin temel bulgular

Yetiștiricilerin \%62.91'i kazlardan elde edilen yağları kullanmakta iken, \%37.09'u bu yağları değerlendirmediklerini belirtmişlerdir. Tüylerin yolunmasında sslatarak yolma (\%52.98) ve kuru yolma (47.02) yöntemleri uygulanmaktadır. Ailelerin \%1.99'u kazlardan elde edilen tüyleri yastık yorgan yapımında kullanmaktadır (Çizelge 4). Boz ve ark. (2014) Yozgat ilinde yapmış oldukları araştırmada yetiştiricilerin \%4'ünün kaz yağını değerlendirdiğini, \%2.5'lik kısmının ise elde edilen tüyün yastık, yorgan yapımı için kullanıldığını belirtmişlerdir. Demir ve ark. (2013) Ardahan ilinde yapmış oldukları çalışmada bir kazdan ortalama 223 g tüy elde edildiğini, yetiştiricilerin ise \%92.1'inin kaz tüylerini yastık yorgan yapımında kullandığını, \%7'sinin sattıklarını ve $\% 0.9$ 'unun da kullanmadan attıklarını bildirmişlerdir. Yapılan araștırmada kaz yağı kullanım oranı Boz ve ark. (2014)'nın elde etmiş oldukları değerden yüksek, kaz tüyü kullanım oranı ise Demir ve ark. (2013)'nın elde etmiş oldukları değerden oldukça düşük bulunmuştur. 
Çizelge 4. İşletmelerin kaz eti, kaz yağı ve kaz tüyü kullanımına göre dağılımı.

Table 4. Distribution of enterprises according to using of goose meat, goose oil and goose feather.

\begin{tabular}{lcc}
\hline Kaz Yağı Kullanımı & İşletme Sayısı & $\begin{array}{c}\text { Toplam İşletme } \\
\text { İçindeki Payı (\%) }\end{array}$ \\
\hline Evet & 95 & 62.91 \\
Hayır & 56 & 37.09 \\
Tüy Yolma İşlemi & & \\
$\quad$ Kuru Yolma & 71 & 47.02 \\
$\quad$ Islatarak Yolma & 80 & 52.98 \\
Kaz Tüyü Kullanımı & & \\
$\quad$ Evet & 3 & 1.99 \\
Hayır & 148 & 98.01 \\
Kaz Eti Tüketim Durumu & & \\
$\quad$ Aile İhtiyacı & 94 & 62.25 \\
Satış & 1 & 0.66 \\
$\quad$ Aile İhtiyacı ve Satış & 56 & 37.09 \\
Yetiştiriciliğe Devam Etme İsteği & & \\
$\quad$ Evet & 128 & 84.77 \\
$\quad$ Hayır & 23 & 15.23 \\
Yüksek Verimli Irklarla Çalışma & & \\
İsteği & & \\
$\quad$ Evet & 139 & 92.05 \\
Hayır & 12 & 7.95 \\
\hline
\end{tabular}

Yetiştiricilerin \%62.25'i kaz etini aile ihtiyacını karşılamak amacıyla, \%0.66'sı sadece satışını yaparak, \%37.09'u ise hem aile ihtiyacını karşılamak hem de satışını yapmak suretiyle kaz eti tüketmektedir. Ankete katılanların \%86.09'u kaz yetiştiriciliğini karlı bir yetiştiricilik faaliyeti olarak görmektedir. Üreticilerin tamamı, geçimi sağlamak amacıyla yapılacak yetiştiricilikte sürü büyüklüğünün 50 ve yukarı olması gerektiğini ifade etmişlerdir. Yetiştiricilerin \%84.77'si kaz yetiştiriciliğine devam etmeyi düşünmekte ve $\% 92.05$ 'i yüksek verimli ırklarla çalışmak istemektedir (Çizelge 4). Taşkın ve ark. (2017) Kırşehir ilinde yapmış oldukları çalışmada kazların piyasaya sunulması ve satışında farklılıklar olduğunu, kazların satışında üreticilerin \%40'ının pazarda satmayı, \%25'inin tüccara satmay1, \%15'inin yakın çevresine satmayı tercih ettiklerini ve \%20'sinin ise satış yapmadıklarını belirlemişlerdir. Satış yapmayan işletmelerin genellikle küçük aile işletmeleri olduğu ve kendi ihtiyaçlarını karşılamak amacıyla yetiştiricilik yaptıklarını belirtmişlerdir. Demir ve ark. (2013) ise yetiştiricilerle yaptıkları görüşmelerde kazlarını satan yetiştiricilerin kazlarının ortalama \%61.53'ünü sattıklarını, geri kalanını ise hane içi tüketimde kullandıklarını belirlemişlerdir. Kazların satışı veya aile içi tüketimde kullanım oranı işletme büyüklüğüne, işletmenin sahip olduğu kaz varlığına, pazarlama imkanlarına ve bölgenin kaz eti tüketim alışkanlıklarına bağlı olarak değişim gösterebilmektedir. Ağrı yöresinde kaz eti genellikle Kasım-Aralık ve Ocak aylarında, kar yağdıktan sonra bulgur pilavı ile birlikte tüketilmektedir. Bunun haricinde kaz etinden tirit, firında ve tandırda kızartma ve kavurma yapılmaktadır. Ayrıca kaz eti, lahana dolması ile keledoş adı verilen yöresel yemeklerde de kullanılmaktadır.

\subsection{Kaz yetiş̧iriciliğinde karşslaşılan sorunlar}

Yetiştiricilerin \%33.11'i "kaz yetiştiriciliğinde karşılaşılan sorunlar nelerdir?' sorusuna herhangi bir yanıt vermemiştir. Ancak hastalıklar nedeniyle meydana gelen kayıplar neticesinde kaz mevcudunun azalması ve hastalıklarla yeterince mücadele edilememesi, devlet destek ve teşviklerinin yetersiz olması ile kazların yağma (tarla ve ekinlere zarar verme) eğiliminin fazla olması üreticilerin en çok karşılaştıkları sorunların başında gelmektedir. Bunun yanı sıra, kazların bakım ve idaresinde çalışacak kimsenin olmaması, makine ve ekipman yetersizliği ve yem fiyatlarının pahalı olması da üreticiler tarafindan yetiştiricilikte karşılaşılan başlıca sorunlar olarak ifade edilmiştir (Çizelge 5). Boz ve ark. (2014) çalışmalarında kazların ekili tarlalara ve evin etrafinda bulunan makine ekipmanlara zarar vermesini, yetiştiricilerin bakım ve beslemedeki bilgi eksikliğini, devlet destek ve teşviklerinin yetersiz oluşunu ve düşük verimli irklarla yetiştiricilik yapılmasını yetiştiricilikte karşılaşılan sorunlar olarak belirlemişlerdir. Demir ve ark. (2013)'nın çalışmalarında yetiştiriciler kaz yetiştiriciliğinin zorlukları arasında yem fiyatlarının yüksek olmasını, kuluçka veriminin düşük olmasını ve bakımlarının uzun sürmesini göstermişlerdir. Taşkın ve ark. (2017) kaz yetiştiriciliğinde karşılaşılan sorunları; yumurta veriminin düşük olması, yem fiyatlarının yüksek olması, kazların korunaksız zirai alanlara zarar vermesi, bakım gerektirmesi ve yan ürünlerinin satılamaması olarak sıralamıştır. Genel olarak kaz yetiştiriciliğinde karşılaşılan sorunlar bölge ayrımı gözetmeksizin birbiri ile benzerlikler göstermektedir.

Çizelge 5. İşletmelerde kaz yetiştiriciliğinde karşılaşılan önemli sorunlar.

Table 5. Important problems of enterprises in goose breeding.

\begin{tabular}{lcc}
\hline $\begin{array}{l}\text { Kaz Yetiştiriciliğinde Karşılaşılan } \\
\text { Sorunlar }\end{array}$ & $\begin{array}{c}\text { İşletme } \\
\text { Sayısı }\end{array}$ & $\begin{array}{c}\text { Toplam İşletme } \\
\text { İçindeki Payı (\%) }\end{array}$ \\
\hline Cevapsız & 50 & 33.11 \\
Bakım ve idarede çalışacak kimse yok & 10 & 6.62 \\
$\begin{array}{l}\text { Destek ve teşvikler yetersiz } \\
\text { Hastalıklar nedeniyle kayıplar }\end{array}$ & 19 & 12.58 \\
yaşanıyor, mevcut sayı azalıyor & 30 & 19.86 \\
$\begin{array}{l}\text { Kazların otlatılacağı alan yetersiz/Yem } \\
\text { fiyatları pahalı }\end{array}$ & 6 & 3.97 \\
$\begin{array}{l}\text { Kuluçka makineleri pahalı, ekipman } \\
\text { yetersiz }\end{array}$ & 7 & 4.63 \\
$\begin{array}{l}\text { Yağmacılık eğilimi fazla } \\
\text { Kaz yetiştiricileri birliği yok }\end{array}$ & 20 & 13.24 \\
$\begin{array}{l}\text { Genç çiftçi projesi gibi üreticiyi teşvik } \\
\text { edici projeler az }\end{array}$ & 1 & 0.66 \\
$\begin{array}{l}\text { Sürünün başında duracak çoban } \\
\text { yok/Yağmacıllı eğilimi fazla }\end{array}$ & 7 & 0.66 \\
\hline
\end{tabular}

\section{Sonuç ve Öneriler}

Ağrı yöresinde kaz yetiştiriciliği öncelikli olarak eti için yapılmaktadır. Kaz eti bölgede hem aile ihtiyacını karşılamada kullanılmakta hem de satışı yapılarak küçük ölçekli işletmelere ekonomik getiri sağlamaktadır. Bölgede uzun ve sert geçen kış mevsimine bağlı olarak kazlar kapalı alanda barındırılmakta ve kuluçkadan çıkan palazlar mevsim şartlarına göre değişmekle birlikte 2-3 haftalık yaştan itibaren açık alana çıkarılmaktadır. Yetiştiricilerin barınaklarda dezenfeksiyon uygulamalarına yeterli düzeyde dikkat göstermemesi kanatlı hayvan hastalıklarının bulaşması ve yayılması açısından ciddi bir sorun olarak görülmektedir. Yapılan çalışmada yetiştiricilerin \%39.74'ü hastalıklar nedeniyle kayıpların yaşandığını belirtmiştir. Bu durum yetiştiricilerin özellikle kaz palazları için uygun bakım ve besleme koşullarını sağlayamamasına, ergin kazlarda ise kötü barındırma şartları ile yetiştiricilik yapılan bölgenin göçmen kuşların göç yolu üzerinde yer almasına bağlı 
olarak yayılan kuş gribi (Avian influenza) gibi kanatlı hastalıklarına dayandırılmaktadır. Hastalıklar nedeniyle meydana gelen kayıplar, devlet teşvik ve desteklemelerinin yetersiz oluşu, kazların bakım ve idaresinde çalışacak kimsenin olmayışı ve kazların yağmacılık eğiliminin fazla oluşu yetiştiricilikte karşılaşılan başlıca sorunlardır.

$\mathrm{Bu}$ çalışmada elde edilen bilgiler anket verilerine dayandığından, yöredeki kazların üretici koşullarındaki geçek verim düzeyleri ile uygun koşullar altında gerçek verim seviyelerinin ortaya konulması için araştırma çalışmalarının yapılmasının gerekli olduğu sonucuna varılmıştır. Bölgede kaz yetiştiriciliği ile uğraşan üreticilerin işletme şartlarının iyileştirilmesi, verim ve kalitenin arttırılması, pazarlama yöntemlerinin çeşitlendirilebilmesi ve sürdürülebilirliğin sağlanması için ihtiyaç duyulan gereksinimler şu şekilde siralanabilir.

-Yetiştiricilikle ilgili eğitim seminerleri verilmeli, üreticilerin teknik bilgi eksiklikleri giderilmelidir.

-Birlik veya kooperatif gibi tarımsal amaçlı üretici örgütleri kurularak yetiştiricilerin bu yapılara üye olmak suretiyle örgütlenme sorunu ortadan kaldırılmalıdır.

-Kurulacak üretici örgütleri vasıtasıyla yetiştiricilerin makine-ekipman, kaliteli damızlık kaz, kuluçkalık yumurta ve palaz ihtiyacı karşılanmalıdır. Devletin sağladığı uygun kredi ve destekler ile sözleşmeli yetiştiricilik uygulamaları teşvik edilmelidir.

-Yetiştiriciler kazlarını günün büyük bir kısmında merada otlatmaktadırlar. $\mathrm{Bu}$ sebeple hem büyükbaş-küçükbaş hayvan yetiştiricileri hem de kaz yetiştiriciliği yapan üreticiler için mera 1slah projeleri hayata geçirilmeli, meradaki yem bitkisi çeşitliliği arttırılmalıdır.

-Kazların akarsu ve göllere ulaşabileceği bölgelerde yer alan köylerde yaşayanların bilinçlendirilmesi gerekmektedir. Akarsu ve göllerin evrensel atıklarla ve tarım ilaçları ile kirletilmesinin önüne geçilmelidir. Özellikle aşırı tarım ilacı kullanımı, kanalizasyon ve hayvan gübresi gibi atıklar ile hastalıklı hayvan leşlerinin akarsuya karıştırılmasının önüne geçilmelidir. $\mathrm{Bu}$ sayede bölgede sıkça rastlanan toplu arı ölümleri ile kaz ölümleri büyük ölçüde engellenmiş olacaktır.

-Kazlar hastalıklara ve olumsuz çevre koşullarına karşı dayanıklı olmasıyla bilinen bir kanatlı türü olmasına rağmen son yıllarda hastalıklar nedeniyle kayıplar meydana gelmektedir. Bu sebeple hastalıklara karşı etkin mücedele sağlanmalı, kaçak hayvan girişlerinin önüne geçilmeli, kamu kurumları ile birlikte hareket edilmelidir.

-Son yıllarda kaz etine olan talep de dikkate alınarak uygun pazar altyapısı oluşturulmalı, hazırlanacak proje ile kaz eti ve diğer yöresel ürünlerin de satışının yapılabileceği yerel halk pazarı kurulmalıdır.

-Kaz eti ve diğer kaz ürünlerinin tanıtımını sağlayacak tanıtıcı gün veya festivaller düzenlenmelidir.

-Ağrı ilinde yetiştirilen kazlardan elde edilen ürünler için coğrafi işaret tescili alınmalı, tesisleşme yönünde atılımlar sağlanmalıdır.

-Uzun vadede kurulacak entegre tesislerde işlenerek paketlenmiş, ambalajlanmış, soğuk hava depolarında muhafaza edilmiş olan kaz eti ve diğer kaz ürünlerinin yurtiçine ve yurtdışına pazarlanması sağlanmalıdır. Ağrı'nın jeopolitik konumu gereği bir sınır ili olması ve İran ile ticaretin büyük bir kısmının gerçekleştiği Gürbulak Sınır Kapısı'na sahip olması bu ürünlerin yurtdışına satışında önemli bir avantaj sağlamaktadır.

\section{Teşekkür}

Ordu Üniversitesi Bilimsel Araştırma Projeleri Yönetim Birimi'ne sağlamış oldukları maddi destekleri için teşekkür ederiz (Proje No: B-1835).

\section{Kaynaklar}

Anonim (2008) SPSS İstatistik Paket Programı.

Arslan C, Tufan, T (2011) Yarı entansif şartlarda beslenen yerli Türk kazlarının besi performansı, kesim özellikleri ve bazı kan parametreleri. Kafkas Üniversitesi Veteriner Fakültesi Dergisi 17(3): 487-491.

Boz MA, Sarıca M, Yamak US (2014) Yozgat ilinde kaz yetiştiriciliği. Tavukçuluk Araştırma Dergisi 11(1): 16-20.

Boz MA (2015) Doğal ve yapay kuluçka ile elde edilen kazların entansif koșullarda büyüme, kesim ve karkas özelliklerinin belirlenmesi. Doktora Tezi, Ondokuz Mayıs Üniversitesi, Fen Bilimleri Enstitüsü, Zootekni Anabilim Dalı, Samsun.

Çelik B (2007) Muş yöresi yerli kazlarında kesim ve karkas özellikleri. Yüksek Lisans Tezi, Afyonkarahisar Kocatepe Üniversitesi, Sağlık Bilimleri Enstitüsü, Zootekni Anabilim Dalı, Afyon.

Demir P, Aksu Elmalı D (2012) Economical analysis of goose breeding commercially by small family farms. World's Poultry Science Journal 68: 5-10.

Demir P, Kırmızıbayrak T, Yazıcı K (2013) Kaz yetiştiriciliğinin sosyoekonomik önemi. Ankara Üniversitesi Veteriner Fakültesi Dergisi 60: 129-134.

Diker O, Deniz T (2017) Kars kültürel ve gastronomik kimliğinde kaz. Doğu Coğrafya Dergisi 22(38): 189-204.

FAO (2013) Food and Agriculture Organization of the United Nations. http://www.fao.org/faostat/en/\#data/QL-. Erişim 22 Eylül 2018.

Karabulut O, Ün H, Çamkerten İ, Garip M, Bulut G (2017) Aksaray yöresi kazlarda kuluçka randımanı üzerine araştırmalar. Bahri Dağdaş Hayvancılık Araştırma Dergisi 6(1): 13-22.

Pingel H (2011) Waterfowl Production for Food Security. Lohmann İnformation 46(2): 32-42.

Taşkın A, Karadavut U, Camcı Ö (2017) Kırşehir ilindeki damızlık kaz yetiştiriciğini etkileyen faktörlerin belirlenmesi. Türk Tarım ve Doğa Bilimleri Dergisi 4(2): 138-144.

Tilki M, İnal Ş (2004a) Türkiye'de yetiştirilen değişik orjinli kazların verim özellikleri. I. kuluçka özellikleri. Turkish Journal of Veterinary and Animal Sciences 28: 149-155.

Tilki M, İnal Ş (2004b) Türkiye'de yetiştirilen değişik orjinli kazların verim özellikleri. II. büyüme özellikleri. Turkish Journal of Veterinary and Animal Sciences 28: 157-163.

TÜIK (2017) Türkiye İstatistik Kurumu. http://www.tuik.gov.tr/PreTablo.do?alt_id=1002. Erişim 21 Eylül 2018. 